nauczycieli, jak i z kręgu ,zwyczajnych” mieszkańców miasta Łodzi. To dzięki ich działalności i inicjatywie powstawały i z powodzeniem funkcjonowały instytucje socjalne i opiekuńczo-wychowawcze.

Joanna Falkowska

\title{
Lużyce po obu stronach Nysy (Die Lausitz auf beiden seiten der Neiße), pod red. Wiesława Jamrożka, Izabeli Kumor-Pilarczyk i Józefa Tarniowego, Żary 2011, ss. 192
}

W dniach 10-13 listopada 2010 r. miasto Żary gościło Dni Kultury Serbołużyckiej. Impreza została zorganizowana przez Kresowe Towarzystwo Turystyczno-Krajoznawcze im. Orląt Lwowskich w Żarach oraz Łużycką Wyższą Szkołę Humanistyczną im. Jana Benedykta Solfy w Żarach, we współpracy ze związkiem Serbołużyczan „Domowina”, oraz Instytutem Serbołużyckim w Budziszynie i Sljepo. Punktem kulminacyjnym imprezy był XI Sejmik Krajoznawczy Polaków Kresowych, odbywający się pod hasłem „Kresowianie chronią dziedzictwo kulturowe Serbołużyczan”. Pokłosiem tegoż sejmiku jest publikacja Łużyce po obu stronach Nysy.

Żary, nazywane stolicą polskich Łużyc, wydają się być najwłaściwszym miejscem dla organizacji przedsięwzięcia, którego celem było przypomnienie Polakom i Niemcom, zamieszkującym obecnie tereny historycznych Łużyc, dziejów i dorobku pierwszych gospodarzy tych ziem, czyli Serbołużyczan - najmniejszego narodu słowiańskiego, ostatnich przedstawicieli tzw. Słowian Połabskich. Należy bowiem z przykrością stwierdzić, że tematyka sorabistyczna wciąż pozostaje dla większości mieszkańców tych ziem, niebędących Serbami Łużyckimi, niemal całkowicie nieznana. Inicjatywa Kresowego Towarzystwa Turystyczno-Krajoznawczego i Łużyckiej Wyższej Szkoły Humanistycznej jest tym bardziej cenna, że Serbołużyczanie, przez wieki skutecznie opierający się wynarodowieniu, obecnie, z powodu całego kompleksu przyczyn, których nie sposób dokładnie tu scharakteryzować, są krytycznie zagrożeni zniknięciem z etnicznej mapy Europy.

Publikację otwiera tekst Wiesława Jamrożka zatytułowany Żarska uczelnia i jej łużyckie konteksty. Autor, prorektor Łużyckiej Wyższej Szkoły Humanistycznej w Żarach, przedstawił uczelnię jako spadkobierczynię żarskich tradycji szkolnictwa (nie tylko) wyższego, a także zaprezentował postać wybitnego Łużyczanina i patrona uczelni - Jana Benedykta Solfy.

Tadeusz Lewaszkiewicz w artykule Przeszłość językowa Łużyc Wschodnich zaprezentował skomplikowaną tematykę dziejów polsko-łużyckiego pogranicza językowego oraz stopniowego zanikania mowy Serbołużyczan na prawym brzegu Nysy Łużyckiej. Jako przykład braku jednoznacznych ocen dotyczących tego zagadnienia, T. Lewaszkiewicz 
przedstawił kontrowersje związane z oceną tzw. Biblii Jakubicy, pierwszego przekładu Nowego Testamentu na język dolnołużycki. Zagadnienia pogranicza językowego Polaków i Serbołużyczan dotyczy także kolejny tekst, autorstwa Bogdana Walczaka, zatytułowany Zachodnia $i$ wschodnia peryferia polskiego obszaru językowego w ujęciu historycznym podobieństwa i różnice. Autor ujmuje jednak problem w innym aspekcie, proponując porównanie omawianego pogranicza językowego z inną granicą, także przebiegającą między różnymi językami słowiańskimi, czyli pograniczem językowym polsko-ruskim.

Kolejne dwa teksty, przygotowane przez autorów pochodzących z lewego, niemieckiego brzegu Nysy, prezentują wybrane uwarunkowania współczesnej egzystencji Serbołużyczan. Sonja Wölke w artykule Język górnołużycki wobec wyzwań współczesności przedstawiła problemy, jakie stoją obecnie przed użytkownikami tego języka oraz perspektywy jego przetrwania i rozwoju w najbliższej przyszłości. Natomiast tekst Dietricha Scholze-Šołty, zatytułowany Religia i narodowość u katolickich Serbołużyczan, zaprezentował historyczne źródła zróżnicowania wyznaniowego Serbołużyczan (na protestanckie Dolne Łużyce i katolickie Górne Łużyce) oraz omówił wpływ tych różnic na ich współczesne życie.

Tytuł artykułu Dolnołużycki byk i mur budziszyński. O łużyckiej symbolice narodowej (na tle znaków tożsamości innych , małych” Stowian) wyczerpująco charakteryzuje jego treść. Autor tekstu, Zdzisław Kłos, wychodząc od opisu herbów Dolnych i Górnych Łużyc, scharakteryzował obrazowo symbolikę, jaką przyjmują grupy etniczne zagrożone rozpłynięciem się wśród silniejszych i liczniejszych sąsiadów.

Krzysztof R. Mazurski zaprezentował historyczne (od początku XIX w.) i współczesne aspekty obecności tematyki sorabistycznej w świadomości Polaków; uczynił to w tekście zatytułowanym Popularyzacja krajoznawstwa Łużyc w Polsce.

Historyk z Budziszyna, Heiko Kosel, artykułem Podział administracyjny okręu Żary w średniowieczu jako dowód znaczenia Łużyckiej Grupy Etnicznej w tym regionie, postarał się przybliżyć czytelnikowi mało znane zjawisko, jakim było istnienie grupy łużyckich zarządców, ekonomów i wójtów, sprawujących w imieniu właścicieli ziemskich funkcje administracyjne w osadach zamieszkanych w większości przez Serbołużyczan. Ukazał też związek między zanikaniem tej grupy a nasilaniem się procesów germanizacyjnych.

Tekst Łużyckie siedziby rodu Schoenaichów na historycznej Ziemi Żarskiej (Terra Sarove) - Dębinka, Gębice, Lipinki, Miłowice, Sieciejów, autorstwa Jerzego Piotra Majchrzaka, przedstawił dzieje łużyckiej gałęzi rodu, znanego w Polsce pod nazwiskiem Krasnodombskich. Z kolei artykuł Jacka Niezgodzkiego, zatytułowany Informacje gospodarcze na starych mapach Dolnych Łuzyc, bogato ilustrowany egzemplarzami z kolekcji autora, prezentuje znaczenie badań kartograficznych w rekonstrukcji różnych aspektów historii społecznej i gospodarczej Łużyc. Natomiast Zbigniew Bujkiewicz w tekście Fundacja Budera a wsparcie ubogich Łużyczan z powiatu żarskiego w latach 1877-1924, opierając się na zasobach żarskiego oddziału Archiwum Państwowego, przedstawił działalność Johanna Michaela Budera i stworzonej przez niego fundacji. Ten interesujący tekst domaga się zakwestionowania stereotypu głoszącego, że stosunki między Niemcami a Serbami Łużyckimi zawsze opierały się na zasadzie poczucia wyższości i ekspansywności tych pierwszych, a poddaństwa i wynarodowienia drugich. 
Kolejne dwa teksty zawarte w publikacji, dotyczą najnowszych dziejów Łużyc. Wiesław Chłopek w artykule Szlakiem bitew, pomników i cmentarzy kresowych żotnierzy 2. Armii Wojska Polskiego na Łużcach opisał wydarzenia ostatnich tygodni II wojny światowej, w wyniku których wschodnia część Łużyc weszła w skład państwa polskiego. Jednym z efektów tej zmiany granic była inicjatywa, opisana przez Piotra Pałysa w tekście Akcja „Mužakow” - próba utworzenia gminy serbołużyckiej po polskiej stronie Nysy Łużyckiej. Epizod ten, a zwłaszcza fakt, że jest on niemal zupełnie nieznany, nawet regionalistom zajmującym się dziejami polskich Łużyc, dowodzi, że na badaczy tej tematyki czeka jeszcze wiele niezwykle interesujących ,odkryć”.

Ostatni artykuł, autorstwa Ignacego M. Dolińskiego, zatytułowany „Zeszyty Łużyckie” jako źródło wiedzy o kużycach, opisuje starania, jakie od początku lat 90. XX w. podjęli badacze związani z warszawskim środowiskiem slawistycznym, a których celem jest promocja w naszym społeczeństwie wiedzy na temat Serbów Łużyckich.

Powyższa prezentacja przekonuje, że zakres i różnorodność tematów poruszonych w książce Łużyce po obu stronach Nysy stanowią jej niewątpliwą zaletę. Nie jest to wszakże zaleta jedyna. Mocną stroną publikacji jest także to, że autorzy artykułów z jednej strony nie ukrywają faktu istnienia białych plam i niedostatecznie zbadanych zagadnień z historii Łużyc, zaś z drugiej - nie próbują pominąć w swych rozważaniach problemów, a nawet niebezpieczeństw, którym Serbołużyczanie muszą współcześnie stawić czoła. Dzięki takiemu podejściu autorów czytelnik, zwłaszcza czytelnik zajmujący się profesjonalnie historią, czuje się zaproszony do podjęcia badań uzupełniających zakres naszej wiedzy o dziejach Serbów Łużyckich. Ponadto, dowiadując się, co grozi istnieniu Łużyczan jako odrębnej grupy etnicznej, może poczuć się zobowiązany do działań wspierających naszych braci w Stowiańszczyźnie.

Konsekwencją okoliczności, że publikacja jest skierowana do polskich i niemieckich sorabistów jest fakt, że pełne teksty wszystkich artykułów zostały opublikowane w obu tych językach. Co więcej, do książki dołączono niezwykle istotne pendant w postaci broszurki zatytułowanej Łužica po woběmaj stronomaj Nysy, zawierającej obszerne streszczenia artykułów w języku górnołużyckim. Dzięki temu każdy kto jest zainteresowany historią Łużyc, a zwłaszcza ci, dla których są one obecnie mała ojczyzna - domowina, mogą dowiedzieć się, jaki język rozbrzmiewał na tej ziemi przez tak wiele lat. 